\title{
the presence of palestinian zionist nation absence in narrating the into being \\ ANNIE PFINGST
}

\begin{abstract}
Who sees? Who is capable of seeing, what, and from where? Who is authorised to look? How is this authorization given or acquired? In whose name does one look? What is the structure of the field of vision?

Ariella Azoulay, Death's Showcase: The Power of Image in Contemporary Democracy ${ }^{1}$

I'm scared of a history that has only one version. History has dozens of versions, and for it to ossify into one leads only to death.
\end{abstract}

Elias Khoury, Gate of the Sun-Bab El Shams ${ }^{2}$

In 2005, as part of my doctoral research, I went to Berlin to see the exhibition 'The New Hebrews: A Century of Art in Israel' ${ }^{3}$ at Martin-Gropius-Bau. 2005 was the thirty-eighth year of the Israeli military occupation of the Palestinian West Bank, East Jerusalem, and the Gaza Strip captured in the 1967 Six Day War, and also a year that saw extensive Israeli construction of the Separation Wall between the West Bank of the Occupied Palestinian Territories and the state of Israel. I experienced 'The New Hebrews' as the narration of the Zionist nation coming into being and observed that, in a historiography and landscape otherwise empty of Palestinian agency and presence, Palestinians appeared, through the work of Israeli photographers and media artists, in the room on Conflicts.

The exhibition was the initiative of Berlin-based Israeli art historian and curator Doreet LeVitte Harten, developed in partnership with Yigal Zalmona, chief curator with the Israel Museum in Jerusalem. Commemorating the forty years of diplomatic relations between Israel and Germany, Doreet LeVitte Harten's curatorial intention for the exhibition was to bring the Hebrew culture that developed in Israel, ${ }^{4}$ a 'new secular country whose roots were in a 
European movement that goes back a century'5, to a German audience. Martin-Gropius-Bau, the partner gallery in which the exhibition would be held, insisted that a member of the Israeli art establishment be involved given 'that this was a sensitive topic' ${ }^{6}$

This essay investigates the frames that simultaneously hide and expose the structure of the field of vision as we encounter the 'contested landscape' ${ }^{\text {'7 }}$ of Palestine-Israel. Reflecting on works in 'The New Hebrews', I consider what authorises our looking, determines who and what registers in our seeing, what frames become visible to our looking even as the Zionist national narrative so coherently registered in 'The New Hebrews' simultaneously disappears Palestinian presence. In the last part of the essay I divert from 'The New Hebrews' to reflect on a photograph taken by Paul Goldman in 1948 and included in the exhibition 'Paul Goldman Press Photographer 1943-1961' at the Camden Proud Gallery, London, in 2006. In particular, I consider the ways in which this image 'lay(s) down routes of reference's as it interrupts the dominant discontinuity between 1948 and the political and geographic present.

In the same way as exhibitions are never politically or culturally neutral spaces, so the beginnings to writing, those 'first step(s) in the intentional production of meaning, ${ }^{9}$ are always moments surrounded by events, both close to home and within the orbit of our political consciousness. In Against Empire, Zillah Eisenstein enjoins us to think thickly about history and the present and to know that at any given moment there is always an already in place and a before, challenging the linear historiography of power. For her 'the present is always shifting, yet at any given moment it is also the surrounding in which we live, so it is both history and the present, simultaneously. Thinking and seeing before the moment-its history — and after —its future possibilities, demands complex knowing.' 10

While I was reflecting on 'The New Hebrews' and its representation of the cultural, political, and historical environments of Palestine-Israel, the Israeli 'teenage' soldier Gilad Shalit was kidnapped across the border from Gaza on 25 June 2006. This moment of the present, by being framed as the beginning/triggering event to an escalation of violence was, in my view, a constructed beginning that effectively silenced the already in place violence of the Israeli military occupation of the West Bank and Gaza and the before of the war of 1948.

On the 24 June 2006, the day before Gilad Shalit's kidnap, the 'Israeli army kidnapped two civilians, a doctor and his brother, from their home in Gaza'. ${ }^{11}$ Detained, we know little of their fate and neither of their names nor, in the broad public arena, did we know of their kidnap. The lives of the Palestinian doctor and his brother, by virtue of being Palestinian are not, as Judith Butler in her work Precarious Life: The Powers of Mourning and Violence posits, 'grievable', their 'vulnerability' not recognised in the same terms as that of someone real, whose life is framed by the familiar within the borders of the nation as we have come to know and participate in it. ${ }^{12}$ And so in this moment, between the body of the 'real' (the soldier) and the body of the 'derealised' (the civilian Palestinians), I entered the void that characterises 
the conflict between Palestinians and the state of Israel. Central to conflict and its attendant violence are disputes over action and response, historical responsibility and representational space. Central to our reading of the cultural artefacts of national identity are disputes over narrative lineage, historiography, and what can legitimately fill the representational space of the nation. The past gets folded under the present, singularity replaces simultaneous and contradictory knowledges, the multiple narratives of place take on a ghostly presence beside a representation of the 'linear historiography of power'. History, and its representation is, as Walter Benjamin has described it, 'the subject of a structure whose site is not homogenous, empty time, but time filled with the presence of the now'. ${ }^{13}$

Both the body of the land and the body of the soldier are deeply embedded in the representation of the cultural space and in the imagination of Israel. Both are sacred; both serve the redemption narrative of Zionist settlement of Palestine; both are present in Israel's narrative of becoming - the body of the soldier and soldiering defining 'the boundaries of the new Jewish collectivity', a society 'deeply concerned with territorial borders as well as (with) body boundaries'. ${ }^{14}$

The land as sacred was both entrance and exit to 'The New Hebrews'. The video-installation Canopy by Itamar Jobani was projected onto the large wall of the stairway to the exhibition. Filmed from a helicopter, the projection travels along the hills, caves and wadis of the 'desert landscape', swooping down over Masada on the mountain-top, across the buildings of the Mar Saba Monastery-providing traces of ancient human habitation, archaeological sites of identity. In all other respects the land appears empty of human habitation. The projection was viewed from beneath a synagogue-like canopy that served as an observation point. In her exposition of the foundational myths of the establishment of Israel, Yael Zerubavel has shown how Masada, through literature, education, youth pilgrimage and ceremony took on significance as a potent symbolic event reflecting the revival of the nation. More than any other trip, 'trekking to Masada through the Judean desert became a rite of passage that activated an experience of primal belonging to an ancient history, land, and identity'. ${ }^{15}$ Masada has been the site for the oath taking ceremony for the Armored Corps and in 1969, 'twentyseven skeletons excavated at Masada and identified as the remains of its last defenders, were given a formal state burial ... Israeli soldiers raised their weapons in salute to the remains of their ancient predecessors, who were brought to rest after a delay of two thousand years. ${ }^{16}$

From within this frame of territorial belonging the main body of the exhibition was entered through the Jug of Tears-the space of the vulnerable, the herded, the massacred, the frightened old man of the diaspora, the space of The Wandering Jew. The 1899 painting by Shmuel Hirszenberg (hung in a replica of the room in the Bezalel Academy of Art and Design established in Tel Aviv in 1905) represented, in the words of the exhibition display, 'the last, dark phase of the Jewish fate before Zionist redemption'. Together with drawings and 
photographs of the pogroms of Eastern Europe, the Wandering Jew established a logic of origins, of beginnings, for the emergence of the New Hebrews. From this beginning/end of pogroms, suffering and death, the exhibition traced the establishment of Israel through fifteen themed 'clusters', beginning with the Jug of Tears and moving on to Zionism, Bezalel, First Fruits, The Hebrew Language-Ivrit, In the name of Utopia-The New Man, In the name of Utopia-Architecture, Shoah, Immigration, Religion, Homeland, War, Temple Scroll, Conflicts, and Alternatives.

In early twentieth-century representations of Palestine, Palestinians appear as poetic references in the painted landscape. A European orientalism romanticised the virtues of Palestinian values and cast itself in their dress and pose- the exhibition included a series of photographs by Avraham Soskin from circa 1915 titled Women in Oriental Dress. Palestinians as people with agency and presence are mostly absent from this early representation. As Palestinian resistance to Jewish settlement increased, even these representations disappear. From al-Nakba ${ }^{17}$ and the establishment of Israel as a state, there has been an ongoing erasure of the lived presence of Palestinians from the Israeli cultural and political space. Edward Said described this erasure when he said that '[p] erhaps the greatest battle Palestinians have waged as a people has been over the right to remembered presence, and with that presence, the right to possess and reclaim a collective historical reality, at least since the Zionist movement began its encroachment on the land'. ${ }^{18}$ Fifty years after The Wandering Jew, the frightened old man of the Jewish diaspora had been banished, replaced by the strong, energetic, athletic Sabra - the New Hebrew- "free", "new" Jews, unsullied by the shameful weakness of exile'. ${ }^{19}$ This sweep across exilic liminal time from origin to return would consequently be embodied in the founding document of the State of Israel. In a redeemed land, 'Jews who "return" to their ancient homeland' would be 'entitled to immediate citizenship by Israel's "Law of Return", eliminating the common requirement of a liminal period associated with immigrant status'. ${ }^{20}$

'The New Hebrews' anchored this unbroken line of attachment to the ancient land through a fragment of the Qumran Temple Scroll. The exhibited scroll, whose text deals with the Temple as revealed to Moses, forms part of the 2000-year-old Dead Sea Scrolls found by Bedouin in caves by the Dead Sea in the 1950s and housed for preservation and display in the Shrine of the Book at the Israel Museum in Jerusalem. Exhibiting the two-metre fragment served to frame the claim to origins, providing material proof of the lineage between the First Hebrews and the New Hebrews and establishing an historical and cultural authority of return. 'The scroll represents a type of utopia', says Levita 'which is why I included it in the exhibition. Ever since the scroll was brought to Israel, after the 1967 Six-Day War, the scroll has provided secular Jews with a kind of legitimization of Israel's hold on that place. ${ }^{21}$ The 1967 capture of the lands that became the Occupied Territories (the West Bank, Gaza and East Jerusalem) 
gave Israel control over the holy sites of the ancestors' land of Eretz Israel transforming 'the war into a religious transcendental experience (turning) land and stones into sacred beings',22 land that would be "non-negotiable, belonging to the "laws of a different hour" .23 In 1977 Menachem Begin (then prime minister of Israel) referred to the West Bank as 'liberated land' rather than as 'administered territories' and is quoted as saying 'we don't use the word annexation. You annex foreign land, not your own country'.24

Within this frame of the territorial belonging of an ancient people returning to a geographic entity grounded in antiquity, Palestinians would by necessity be regarded as transitory, outside of history and outside of place, " "inhabitants" contained within other historical narratives'. ${ }^{25}$ Yehudit Kirstein Keshet, a founding member of Machsom Watch, ${ }^{26}$ describing her 'first encounter with Israeli reality, and the denial of that reality' when she came to Israel in the 1950s, talks about the ways in which 'apart from their deserted fields and fig trees, the "Arabs" merely lurked silently in the shadows of our nightmares'. ${ }^{27}$ Yehudit Kerstein Kirshet outlines what she regards as the

ambivalence (that) lies deep at the heart of Israeli thinking and culture: the longing for peace versus entrenched militarism, the hegemony of European culture versus that of Jews from Arab lands and the denial of the persistent, ghostly presence of those absentees, the Palestinians, amid the ruins of their homes and their neglected fields. ${ }^{28}$

The models for new Jewish settlements, moshav, kibbutzim and towns shown in the cluster on planning and architecture of 'The New Hebrews' - In the Name of Utopia - Architecturepresent European modernist plans for an uninhabited geographic space, terra nullius. Negating the exile of the twisting, narrow, old streets of the shtetls and ghettos of Europe building the modern state would underpin a narrative of 'entering history through territory'. ${ }^{29}$

In 'The New Hebrews' Palestinians became visible in the room on Conflicts where their presence was framed by the Separation Wall through the work of photographer Miki Kratsman, the occupation and the checkpoints of the West Bank through Avi Mograbi's video work and David Tartakover's posters, the Intifada through the photographs of Pavel Wolberg, and as refugees in Micha Kirshner's portraits.

In the eight-minute film Detail (2004) by Avi Mograbi, a group of Palestinians walk towards a checkpoint and try to negotiate with Israeli soldiers for passage to an ambulance. The IDF soldiers are in a tank; they never leave the vehicle. The voice of the IDF soldier, muffled by the armour of the vehicle he is in, comes over the loudspeaker to halt the movement of the group walking along the dusty road. The location is not specific-an Israeli checkpoint somewhere in the occupied territories. The soldier, anonymous, protected, his power emanating from the operation of the tank, tells the Palestinians to 'Stop ... Go home'. The ambulance, when it arrives, is sent back by the soldiers. A young girl, afraid, cries. The Palestinians, 

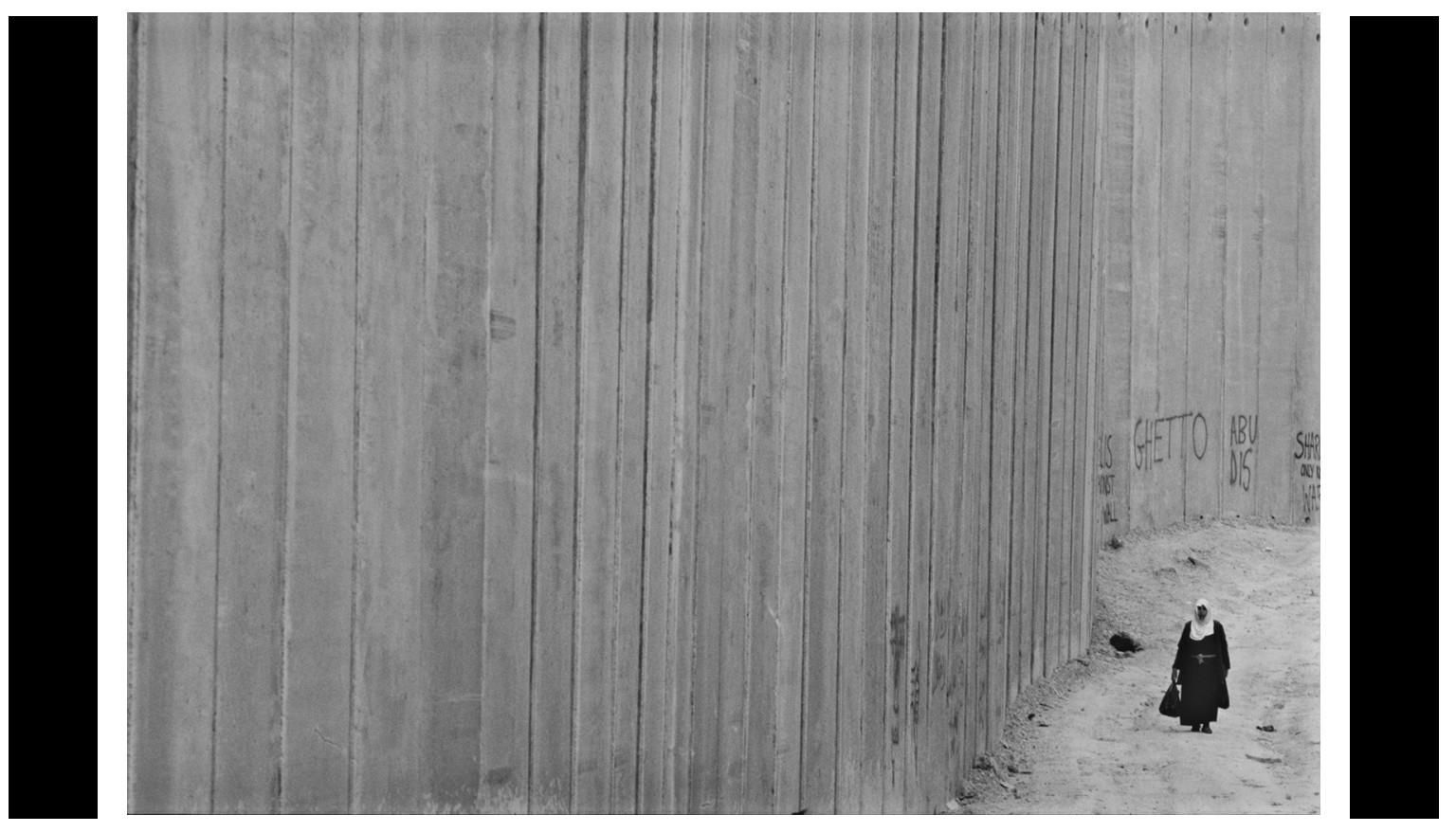

Miki Kratsman, Abu Dis, 2003,

Courtesy Miki Kratsman

protected only by their clothing, are bodies of flesh, exposed and vulnerable, their existence precarious in the land over which they have no power or control.

A large photograph by Miki Kratsman brought the 'architecture of occupation'30 into 'The New Hebrews'. Other than those manning the army jeeps patrolling the Separation Wall, few Israelis would pass along this part of East Jerusalem as the Wall cuts the Palestinian community of Abu Dis off from its East Jerusalem neighbourhoods. The local Palestinian garage metres from the Wall used to be the busiest in East Jerusalem. Now it is quiet. An emptiness, together with the immensity of the Separation Wall in Miki Kratsman's Abu Dis, fills the exhibition space with a question-with what authorisation do we look, what are we capable of seeing of the contested landscape of Palestine in images located in the cluster on Conflicts between the Temple Scroll and Alternatives, between sacred origin and 'the wishful thinking ... for peace'? ${ }^{31}$ What do we know of this place called Abu Dis and what about the life of this woman, whose name we do not know, walking beside the concrete wall? Notwithstanding the critical tension and discomfort evident in the works of young, contemporary Israeli artists in the exhibition (especially in the cluster on War) the trajectory established from the pogroms of the Jug of Tears, through the new body of the Sabra and the building of utopian settlements, to the memorials for the fallen soldiers of Israel's wars, gives no space for the narrative of Abu Dis. Together with Shuf'at, Bil'in, Qalqilya and Tulkarem (amongst countless Palestinian communities), Abu Dis can be considered the latest frontier between the state and its borderland as the Separation Wall, 'this obstacle where security-geography-demography dramatically collide', ${ }^{32}$ permanently demarcates the new temporary borders of the nation state. 
The section of the Separation Wall that we see in Miki Kratsman's photograph of Abu Dis is part of a construction that is (both built and planned) 734 kilometres in length. For much of its length an electronic fence, the Separation Wall, encloses Palestinian towns and cities with concrete panels eight metres in height, topped with barbed wire, with observation towers and electronic surveillance. ${ }^{33}$ It goes deep into Palestinian territory, separating Palestinian villages from their fields, demolishing houses and the Palestinian cultural landscape, destroying hundreds of dunums of agricultural land, olive groves and infrastructure in its construction while it simultaneously folds West Bank settlements (illegal under international law) into Israel's geographic and political space.

Ariella Azoulay recounts how a year after the November 1948 Armistice Agreement between Jordan and Israel was drawn a 'fence was erected along the dividing zone, none of the parties liked the idea of such a conspicuous delineation of the borderline, so the fence was officially named a "fence for the prevention of infiltration". Infiltration had to be fought without a formal recognition of the transgressed boundary.'34

Palestinians are located within this geographic, political and cultural space-simultaneously the site of sacred settlement and of military occupation-as the enemy, the threat to Eretz Israel. Conflict and violence envelop all representations and narratives about both Palestinian presence and Palestinian absence. From their designation as 'infiltrators', to that of present absentees under the Absentee Property Law of 1950, to the war on terror, Palestinians have come to constitute what Judith Butler describes as the 'spectral infinity of the enemy'. ${ }^{35}$ They are simultaneously present in their absence and absent in their presence-in the ruins of the buildings, olive groves and orchards of the villages destroyed in 1948; as citizens living within the 1948 borders of Israel, often within sight of their destroyed villages or in communities unrecognised as settlements by the Israeli state; and as the oldest and largest single refugee community worldwide. Palestinians, 'excluded from an ontology of the real', ${ }^{36}$ nevertheless animate resistance to the discourse of Zionist settlement of an empty land waiting redemption. 'If violence is done against those who are unreal', writes Judith Butler:

then, from the perspective of violence, it fails to injure or negate those lives since those lives are already negated. But they have a strange way of remaining animated and must be negated again (and again) ... Violence renews itself in the face of the apparent inexhaustibility of its object ... The derealization of the "Other" means that it is neither alive nor dead, but interminably spectral. ${ }^{37}$

In the foreground of the large format photograph The Street (2002) shown in the cluster Conflicts alongside Abu Dis 2003, eight one-metre square concrete blocks sit horizontally across a road that disappears vertically into the horizon. It forms part of Miki Kratsman's project Maschsom (roadblock). The street is anonymous; it could be anywhere in the Occupied 
Palestinian Territories; it could be any one of sixty roadblocks that in April 2007 formed part of the 549 obstacles (including checkpoints, earth mounds and road gates) that restricted Palestinian movement in the West Bank. ${ }^{38}$ In this environment the camera acts to make visible to the public what Anat Zanger in her discussion about contemporary Israeli film describes as a 'third space' of border transference sites, control points and road blocks ${ }^{39}$ — those spaces and places that exist outside the seeing eye of the Israeli public, beyond the 1948 borders of the state, within imaginary Erez Israel, a militarised frontier of security and land control. In the Israeli political imagination checkpoints and roadblocks serve as protection against Palestinian infiltration across, and transgression of, the (temporary) border.

Commenting on grappling with the appropriate position from which to photograph the roadblocks, Miki Kratsman wrote: 'I am not a Palestinian and could not simulate their suffering. I am not hurt by the roadblocks that are positioned there by my people ... This series of photographs were taken from the correct position, the place where I can express my point of view as a photographer. ${ }^{40}$ Through what Judith Butler describes as an 'act of delimitation' in which reality is interpreted through framing, ${ }^{41}$ Street and Abu Dis present an uncannily emptied space, the restricted, enclosed, silent geography of the cultural and political border.

Two portraits by Micha Kirshner brought Palestinian refugees into the cluster on Conflicts. The first, titled Aisha el-Kord in Khan Younis Refugee Camp 1988, from the series Intifada, is an aesthetically beautiful black and white image of a mother with her baby stretched out across her lap. Her eyes are lightly closed; her baby is sleeping. The mother is dressed in black, her head covered; her child is dressed in white; the studio light falls on her face, her hands and the body of her child. The second photograph, Palestinian Mother with Child, from the series The Wounded of the Intifada, shows a small girl-child, crying, naked, with a wound to her left eye. A woman, her mother, holds her hand. The mother's body, dressed in black, takes up a third of the image; we can see her feet but not her upper body or her face. Micha Kirshner photographs Palestinian refugees in his studio and in the photograph of the Palestinian mother in Khan Younis, there is no trace of the refugee camp, of Khan Younis or of Gaza. The narrative of the second photograph is more readily identifiable. Rona Sela in her essay for 'The New Hebrews' catalogue narrates the story of the photograph and of the child. The one-year-old child, Huda Massuda, from the Jabalya refugee camp in Gaza, was injured by a rubber bullet while escaping a grenade attack on her house during a demonstration. ${ }^{42}$ Initially taken for a daily Israeli newspaper, Micha Kirshner's portraits were later enlarged for museum exhibition. As portraits framed by the aesthetic of the museum rather than the immediacy of journalistic reporting, the people represented are removed from their cultural, political and physical environment. While what 'counts within the frame' is an 
intense attention to the people in the portraits, they are simultaneously placed in what Rona Sela describes as a 'sterile zone', a sterility that, nonetheless, 'intensifies the severity of their wounds'. 43

Susan Sontag was particularly concerned about the aesthetisisation of suffering and questioned the capacity of the photographic image to shock us into ethical judgement. In Regarding the Pain of Others she wrote that 'the photographic image, even to the extent that it is a trace ... cannot be simply a transparency of something that happened. It is always the image that someone chose; to photograph is to frame, and to frame is to exclude'. ${ }^{44}$ It remains a point of individual judgment whether the aesthetic representation and framing of suffering and of being human brought to our attention by Micha Kirshner's studio portraits indeed 'shock us into ethical judgment'. For Rona Sela, Micha Kirshner 'aestheticized pain and suffering' and, although the images have the capacity to 'astonish', she posits the problematic that one can see them either as a critique that reveals, or as a photographic depiction that affirms, the relationship between the occupier and the occupied. ${ }^{45}$

The head and face of the child in Micha Kirshner's portrait Palestinian Mother with Child appears again in David Tartakover's poster Pain (1989), also exhibited in 'The New Hebrews' cluster Conflicts. Through this repetition of the face of the child, the trace of the violence of the Intifada circulates as critical discourse. The image can be said to be haunted by history ${ }^{46}$ the immediate and local as well as geographically and historically broader history of the conflict that wraps around Huda Massuda's small life, but also the history of the mode in which the photograph was taken and its endless reproducibility. The child becomes emblematic of the violence of the Israeli military occupation.

The simultaneously exposed and hidden narrative that is the political geography of Palestine-Israel is illuminated in the photograph by Miki Kratsman titled Gilo 2001, exhibited in the room on Homeland in 'The New Hebrews'. It shows a section of concrete panels (a wall) on which a mural represents a view of the Palestinian landscape, a 'picturesque Arabian pastoral, a depopulated landscape ${ }^{247}$ at the same moment that the real Palestinian village of Beit Jala can be seen on the hillside across the valley. The row of panels with the mural that Miki Kratsman photographed in 2001 is still there-the Palestinian landscape is rendered in soft tones, rolling hills and trees, the buildings part of the landscape, 'an artistic replica of the disappearing view'. ${ }^{48}$ It was built in 2000 at the start of the Al Aqsa Intifada to protect and shield the Israeli settlement and painted to soften the impact of the wall for Gilo's residents. In considering how the mural wall frames the landscape, W.J.T. Mitchell has written that 'Gilo's wall reveals itself as a seam or scar in the landscape, a border that simultaneously divides a lived, social space and overcomes that division by veiling it with an illusion'. ${ }^{49}$ Miki Kratsman's Gilo portrays the 'vulnerable open space between the Gilo settlement and 
Beit Jalla, ${ }^{50}$ a vulnerability that is simultaneously hidden and exposed as Palestinian presence is disappeared and revealed.

In 2007 murals of peace doves and dancing circles, of biblical scenes, the land hazy and empty, the bodies of women and men in flowing robes lifting up softly rounded babies, tending the cultivation of herbs and plants are painted on another wall of concrete panels alongside the road on the Gilo hillside. At the bottom of the hill, across the valley, behind the fence and concrete wall that lower down the hill forms the 'real' and 'effective' Separation Wall, the people of Beit Jala, Bethlehem and Aida refugee camp live precariously with food insecurity and a humanitarian crisis. ${ }^{51}$

The precarious vulnerability of Palestinian lives are the concern of the women on Machsom Watch who witness and testify to human rights violations and intervene on behalf of Palestinians at the Israeli checkpoints in the Occupied Palestinian Territories. The reports and photographic evidence they collect reveals one of the conditions of the occupation, at the same time bringing fragments of a military reality and the fragmentation of Palestinian life to an Israeli public. They talk about their actions as having 'acquired an alternative authority, one rooted in a civilian perspective' challenging as it does the 'sacred text' of the Israeli army spokesman. ${ }^{52}$ The checkpoints Machsom Watch witness and document are located in the same transitory geographic space as the roadblock in Miki Kratsman's Street: they are "not border crossings—but demarcate territorial boundaries, an imaginary line between "ours" and "theirs", ${ }^{53}$ The women of Machsom Watch testify to the "conditions and actions of occupation - the refusal to answer accompanied by the refusal to look-that deny the existence of the other'. ${ }^{54}$

In the conflict between Palestinians and the state of Israel, 1948 stands as an eternally present moment in the sense that Edward Said gave us of the eternally present moment as a moment of beginnings. ${ }^{55}$ It was the events of 1948 that brought Palestinians to the refugee camps of Ayda near Bethlehem in the West Bank and Jabalya and Khan Younis in the Gaza Strip. The 1948 Israeli War of Independence and Palestinian al-Nakba do not factor as central motifs in 'The New Hebrews'. I want to conclude by considering the ways in which a Jewish documentary sensibility might insert the lived experience of Palestinians and the historically central moment of 1948 by looking at one work by the photographer Paul Goldman.

In 1948 Paul Goldman (a photographer who immigrated to Israel from Budapest in 1940) took a photograph titled 'Arab' villagers after their expulsion from Bir Burin region (today Be'erotayim in the Sharon) fleeing toward Tul Karm, $1948 .{ }^{56}$ In his essay for the catalogue of the 'Paul Goldman Press Photographer 1943-1961' exhibition at the Camden Proud Gallery London in 2006, Yeshayahu Nir makes the point that Paul Goldman was among the few photographers who photographed what he describes as 'this dark historical moment' 

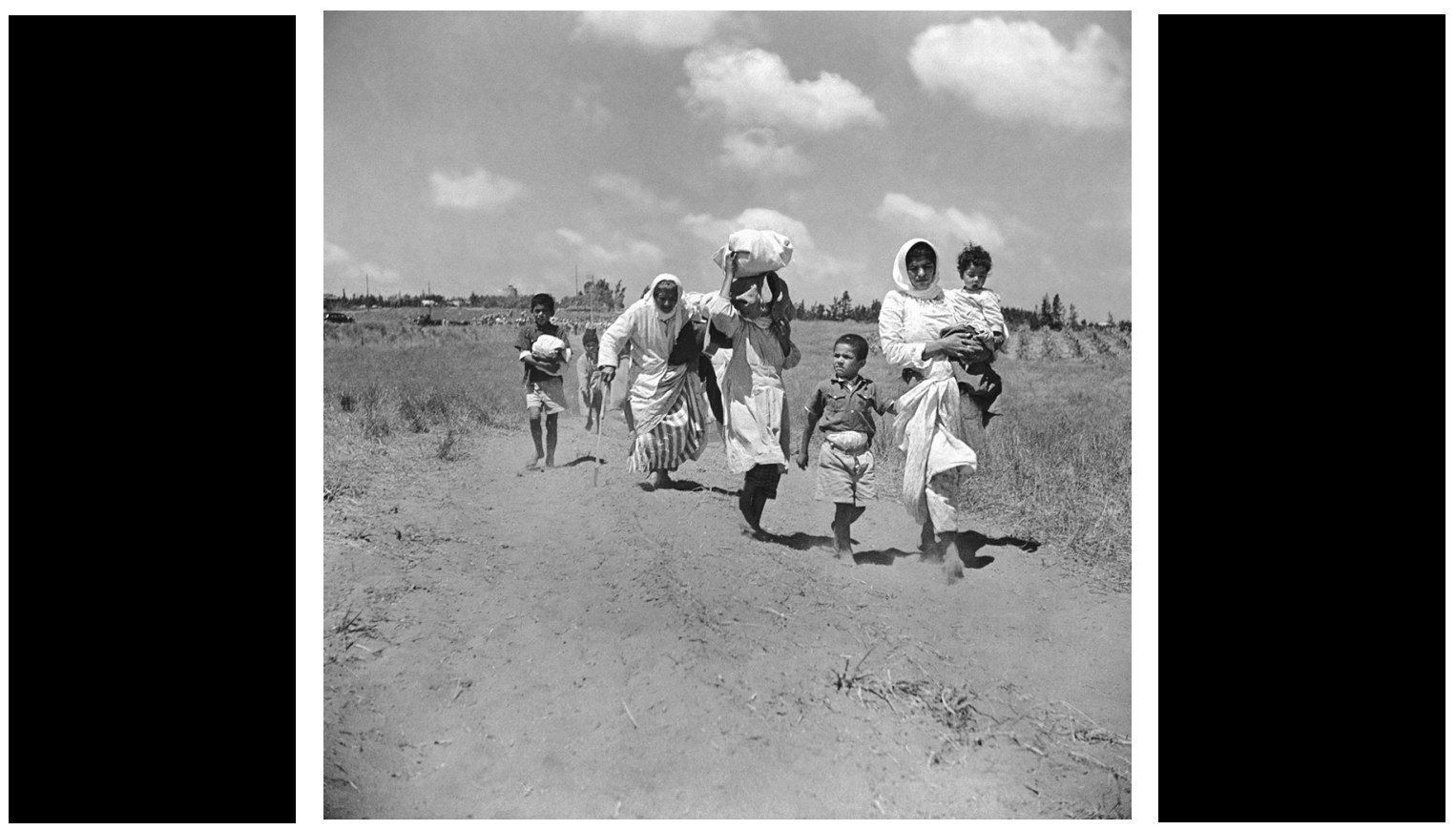

referring to the 'flight and expulsion of the Palestinian Arabs'. He relates that Paul Goldman was precise and laconic in captioning his images and that, although the photograph was published in Devar Hashavu (an Israeli journal) the caption was changed to read, 'Arab women with their children were returned to Arab territory' ${ }^{57}$ The caption to Paul Goldman's photograph, the 'missing voice ... expected to speak for truth', ${ }^{58}$ frames Paul Goldman, 'Arab' villagers after their expulsion from Bir Burin region (today Be'erotayim in the Sharon) fleeing toward Tul Karm, 1948 Courtesy Spencer the historical interpretation as sovereignty and the border are delineated M. Partrich through text. Yeshayahu Nir himself comments on the changed citation by asking 'Being returned? Did they flee to Jewish territory during the fighting? Were we aware at the time of the different aspects and meaning of what was taking place? Are we today? ${ }^{59}$ The coherence of Paul Goldman's evidence of dispossession is disrupted and the complex, contradictory, and precarious nature of the establishment of the Zionist state is refused. While Paul Goldman's caption ensures the agency and active presence of the Palestinian women and children, the changed caption takes their agency away-they are 'returned' even as the possibility of return is denied.

Judith Butler has argued that 'perhaps our inability to see what we see is also of critical concern. To learn to see the frame that blinds us to what we see is no easy matter. ${ }^{60}$ When we can see clearly the layered discourses that frame the presence of Palestinian absence in the Zionist historiography of the creation of the state of Israel, then finally 'grief, rage and outrage may be born precisely in what we see, since what we come to see is a frame, an interpretation of reality, that ... we refuse' ${ }^{61}$ Edward Said maintained that 'the Palestinian 
Intifada put an end to the idea of Palestinian silence and absence'. ${ }^{62}$ It may be through the photographs that the children of Aida and Balata refugee camps take that we can see the 'narrative coherence'63 of life lived precariously in the 'wild zone of absolute power and terror' ${ }^{64}$ that characterises belligerent military occupation.

ANNIE PFINGST is writing on the discourses that frame the Palestinian right of return as part of her doctoral research at the University of Technology, Sydney. Her work as an artist and her research are concerned with embodied knowledges of absence-presence and the layered narratives of place; with memory and the constituting links between scattered geographies and contradictory and simultaneous histories; and with justice in the application of international human rights law. <ann.m.pfingst@student.uts.edu.au>

1. Ariella Azoulay, Death's Showcase: The Power of Image in Contemporary Democracy, trans. Ruvik Danieli (Ruvk Danieli), MIT Press, Cambridge, Mass., London, 2001, p. 4.

2. Elias Khoury, Gate of the Sun; Bab El Shams, trans. Humphrey Davies, Harvill Secker, London, 2005. p. 275.

3. The paper refers to the exhibition throughout as 'The New Hebrews'.

4. Dana Gilerman, 'Tumarkin is Not the Only One Missing from the List', Ha'aretz, 7 April 2005, www.haaretz.com/hasen/objects/pages/Print ArticleEn.jhtml?itemNo=562036.

5. James Woodall, 'Creation of a Nation', Financial Times, Arts and Weekend Art and Design, 13 May 2005.

6. Gilerman.

7. Barbara Bender and Margot Winer (eds), Contested Landscapes: Movement, Exile and Place, Berg Oxford and New York, 2001, Introduction.

8. Susan Sontag, Regarding the Pain of Others, Penquin, London, 2004, p. 76.

9. Edward Said, Beginnings: Intention and Method, Basic Books Inc., New York, 1975, p. 5.

10. Zillah Eisenstein, Against Empire: Feminisms, Racism and the West, Zed Books, London and New York, 2004, p. 4

11. Noam Chomsky, and Gilbert Achcar, Perilous Power: The Middle East and US Foreign Policy: Dialogues in Terror, Democracy, War and Justice, intro. and ed. Stephen R, Shalom, Paradigm Publishers, Boulder, Co and London, 2007, p. 239. See also Jonathan Cook, 'Kidnapped by Israel: The British Media and the Invasion of Gaza',
Medialens, 2006, <http://www.medialens.org/ alerts/06/060630_kidnapped_by_israel.php>

12. Judith Butler, Precarious Life: The Powers of Mourning and Violence, Verso, London, 2004, pp. 19-49.

13. Walter Benjamin, Illuminations, intro. and ed. Hannah Arendt, Fontana, London, 1973, p. 263

14. Meira Weiss, The Chosen Body: The Politics of the Body in Israeli Society, Stanford University Press, Stanford, 2002, p. 5

15. Yael Zerubavel, Recovered Roots: Collective Memory and the Making of Israeli National Tradition,

University of Chicago Press, Chicago and London, 1995, p. 124.

16. Zerubavel, Recovered Roots, pp. 129-30.

17. Palestinians call the war of 1948 'the catastrophe'.

18. Edward Said, 'Palestine: Memory, Invention and Space', in Ibrahim Abu-Lughod, Roger Heacock and Khaled Nashef (eds), The Landscape of Palestine: Equivocal Poetry, Birzeit University Publications, Birzeit, Palestine, 1996, p. 12

19. Amos Elon, The Israeli's: Founders and Sons (1971) quoted in Weiss, p. 24

20. Yael Zerubavel, "The "Mythological Sabra" and Jewish Past: Trauma, Memory, and Contested Identities', Israel Studies, vol. 7, no. 2, p. 117.

21. Gilerman

22. Idith Zertal, 'From the People's Hall to the Wailing Wall: A Study in Memory, Fear and War', Representations, vol. 69, Winter 2000, p. 113.

23. Zertal, p. 121

24. Nur Masalha, Imperial Israel and the Palestinians: The Politics of Expansion, Pluto Press, London, 2000 , p. 73. 
25. Ariella Azoulay, 'With Open Doors: Museum and Historical Narratives in Israel's Public Space' in Daniel Sherman and Irit Rogoff (eds), Museum Culture: Histories, Discourse, Spectacles, Routledge, London, 1994, p. 87.

26. Machsom Watch is an organisation of Israel women monitoring the checkpoints in the Occupied Palestinian Territories.

27. Yehudit Kirstein Keshet, Checkpoint Watch: Testimonials from Occupied Palestine, Zed Books, London and New York, 2006, p. 2.

28. Kirstein Keshet, p. 3.

29. Oren Yiftachel, 'Territory as the Kernel of the Nation: Space, Time and Nationalism in Israel/ Palestine', Geopolitics, vol. 7, no. 2, Autumn 2002, p. 227.

30. See Eyal Weizman, Hollow Land: Israel's Architecture of Occupation, Verso, London, 2007.

31. "A Brief Introduction to the "clusters" of the exhibition "The New Hebrews: A Century of Art in Israel"' Pressmaterial English, Martin-GropiusBau, Berlin, 2005.

32. Kirstein Keshet, p. 89

33. Weizman, p. 161 .

34. Azoulay, p. 188

35. Butler, Precarious Life, p. 34

36. Butler, Precarious Life, p. 33

37. Butler, Precarious Life, pp. 33-4.

38. United Nations Office for the Coordination of Humanitarian Affairs (OCHA) occupied Palestinian territory, West Bank and Gaza Strip Closure Maps, April 2007, p. 1.

39. Anat Zanger, 'Blind Space: Roadblock Movies in Contemporary Israeli Film', Shofar: An Interdisciplinary Journal of Jewish Studies, vol. 24, no. 1, 2005, p. 39.

40. Miki Kratsman, 'Machsom' in Gordon Hon (ed.), What Remains to be Seen: Art and Political Conflict: Views from Britain, Israel, Palestine and Northern Ireland, Multi Exposure, London, 2004, p. 32.

41. Judith Butler, 'Photography, War, Outrage', Modern Language Association of America, vol. 120, no. 3, May 2005, p. 823

42. Rona Sela, "Vom "goldenen Jerusalem" zum "brennenden Tel-Aviv". Von der zionistischen zur kritischen Fotographie' ("From "golden Jerusalem" to "burning Tel-Aviv": From Zionist to critical photography'), Yelena Gedge (trans. 2006), in Die Neuen Hebraer: 100 Yahre Kunst in Israel (The New Hebrews: 100 Years of Art in Israel), MartinGropius-Bau, Berlin, 2006. Witnesses to the occupation have recorded a number of stories of young Palestinian children being injured by rubber bullets and tear-gas grenades, losing eyes, suffering burns, their mothers injured or killed. See also Ann Lesch, Introduction to Baramki Azar, Palestine: A Photographic Journey, University of California Press, Berkeley, 1991

43. Sela, p. 464

44. Sontag, Regarding the Pain of Others, p. 41

45. Sela, p. 464

46. Eduardo Cadava, Words of Light: Theses on the Photography of History, Princeton University Press, Princeton, 1997, Preface: photagogos.

47. W.J.T. Mitchell, 'Christo's Gates and Gilo's Walls', Critical Inquiry, vol. 32, no. 4, 2006, p. 590.

48. Ruth Malul Zadka "The 'Transparent' Wall in Jerusalem's Gilo Neighbourhood" (MA thesis, University of Leeds in Israel, Tel Aviv, 2003) in Mitchell, p. 588

49. Mitchell, p. 590

50. Mitchell, p. 590

51. On 22 March 2007 it was reported that one-third of Palestinians in the West Bank and Gaza were food insecure according to a report by the United Nations World Food program (WFP) and Food and Agriculture Organization (FAO) $<$ www.irinnews.org/Report.aspx?ReportId $=70856>$.

52. Kirstein Keshet, p. 48.

53. Kirstein Keshet, p. 57

54. Kirstein Keshet, p. 60

55. Said, Beginnings, p. 257.

56. Paul Goldman Press Photographer, 1943-1961, Eretz Israel Museum, Tel Aviv, 2004, p. 16.

57. Yeshayahu Nir, 'Paul Goldman: Homage to a Press Photographer', Paul Goldman Press Photographer, 1943-1961, Eretz Israel Museum, Tel Aviv, 2004 p. 16.

58. Susan Sontag, On Photography, Allen Lane Penquin Books, London, 1978, p. 108.

59. Nir, p. 16.

60. Butler, Photography, War, Outrage', p. 826.

61. Butler, 'Photography, War, Outrage', p. 827.

62. Said, 'Memory, Invention and Space', p. 18.

63. Butler, 'Photography, War, Outrage' discusses Susan Sontag's assertion that 'photographs render truths in a dissociated moment and offer us only fragmented or dissociated truths ... lacking narrative coherence', p. 823.

64. Susan Buck-Morss, Dreamworld and Catastrophe: The Passing of Mass Utopia in East and West, MIT Press, Cambridge, Mass. and London, England, 2000 , p. 20. 